\title{
Respon Tanaman Jagung (Zea mays L.) terhadap Sistem Olah Tanah pada Musim Tanam Ketiga di Tanah Ultisol Gedung Meneng Bandar Lampung
}

\author{
Ahmad Hidayat, Jamalam Lumbanraja, Setyo Dwi Utomo \& Hidayat Pujisiswanto \\ Jurusan Agroteknologi, Fakultas Pertanian, Universitas Lampung \\ Jl. Prof. Soemantri Brojonegoro, No. 1 Bandar Lampung 35145 \\ Email:j.lumbanraja53@gmail.com
}

\begin{abstract}
ABSTRAK
Jagung merupakan bahan pangan pokok kedua setelah beras dan bahan utama pembuatan pakan. Penelitian bertujuan untuk menetapkan produksi, serapan hara dan nilai ekonomis tanaman jagung. Penelitian dilaksanakan di Laboratorium Lapangan Terpadu, Universitas lampung Bandar Lampung, mulai bulan Mei 2015 sampai Agustus 2015. Analisis tanah dan tanaman dilakukan di Laboratorium Ilmu Tanah Universitas Lampung dari bulan September 2015 sampai dengan Februari 2016. Rancangan penelitian adalah Rancangan Acak Kelompok (RAK) dengan 4 perlakuan yaitu olah tanah minimum, olah tanah minimum + herbisida, olah tanah sempurna, olah tanah sempurna + herbisida dan masing-masing perlakuan diulang sebanyak 4 kali. Variabel yang diamati adalah tinggi tanaman, jumlah daun, analisis tanah, analisis tanaman, produksi jagung, bobot basah dan bobot kering tanaman jagung, uji korelasi dan uji ekonomis. Hasil penelitian menunjukkan bahwa sistem sistem olah tanah minimum berpengaruh nyata meningkatkan tinggi tanaman, bobot brangkasan panen dan $\mathrm{C}$ terangkut pada bonggol jagung, kandungan P-tersedia dan nilai ekonomis.
\end{abstract}

Kata kunci: Jagung,olah tanah, Ultisol

\section{PENDAHULUAN}

Jagung merupakan bahan pangan pokok kedua setelah beras yang digunakan sebagai sumber karbohidrat serta digunakan sebagai bahan baku industri dan pakan ternak. Meningkatnya jumlah penduduk dan perkembangan industri saat ini akan langsung berdampak pada peningkatan permintaan atau konsumsi jagung (Indrasari dan Syukur, 2006). Total produksi jagung di Indonesia tahun 2014 mencapai 19.008.426 ton dengan luas panen 3.837.019 ha setara 4,95 $\mathrm{t} \mathrm{ha}^{-1}$ (BPS, 2015), sementara total kebutuhan jagung tahun 2015 diperkirakan mencapai 20.900.000 ton (Direktorat Jenderal Tanaman Pangan, 2015), sehingga perlu peningkatan produksi sebesar 1.891.574 ton dengan meningkatkan produktivitasnya menjadi 5,44 $\mathrm{t} \mathrm{ha}^{-1}$ atau dibutuhkan penambahan luas panen sebesar 382.136 ha.

Rendahnya produksi jagung di tingkat petani dapat mempengaruhi produksi secara Nasional. Hal ini dimungkinkan dengan penggunaan benih, pengolahan tanah dan populasi tanaman yang tidak sesuai, teknologi budidaya yang kurang memadai, pola tanam yang tidak sesuai, ketidaktersediaan air dan kondisi sosial ekonomi petani. Pengolahan tanah secara intensif yang dilakukan terus menerus tanpa melakukan konservasi akan berdampak pada penyusutan kandungan bahan organik tanah, dan kandungan unsur hara lainnya pada tingkat sangat rendah (Utomo, 2006). Padahal bahan organik penting dalam menunjang produktivitas tanaman dan sekaligus mempertahankan kondisi lahan tetap produktif (Eriawan dan Nadimin, 2011).

Menurut Rachman, dkk., (2004) faktor penentu dalam keberhasilan sistem olah tanah konservasi (OTK) adalah pemberian bahan organik dalam bentuk mulsa yang cukup. Penggunaan mulsa pada permukaan tanah dapat menghambat pertumbuhan gulma, laju kehilangan air, dan laju pemadatan tanah. Tanah-tanah dengan kandungan bahan organik yang tinggi memiliki struktur yang baik sehingga sistem perakaran tanaman mudah berkembang sebagai akibat dari pemantapan agregat serta menurunkan plastisitas dan bulk density (BD) sehingga unsur hara tanah tahan unsur hara terhadap erosi (Mustafa, dkk., 2012). Penelitian ini bertujuan menetapkan produksi, serapan hara dan nilai ekonomi tanaman jagung pada musim tanam ketiga.

\section{BAHAN DAN METODE}

Penelitian menggunakan indikator tanaman jagung yang sebelumnya ditanami tanaman jagung (musim pertama) dan ubi kayu (musim kedua) di Laboratorium Lapang Terpadu, Fakultas Pertanian, Universitas Lampung. Analisis tanah dan jaringan tanaman dilaksanakan di Laboratorium Ilmu Tanah, 
Fakultas Pertanian, Universitas Lampung. Penelitian dilakukan pada bulan Mei-Agustus 2015. Bahan yang digunakan untuk penelitian ini adalah benih jagung BISI-2, herbisida IPA Glifosat $300 \mathrm{~g} \mathrm{l}^{-1}+2$,4-D 100 $\mathrm{g} \mathrm{l}^{-1}$, sampel tanah, pupuk Urea, TSP, $\mathrm{KCl}$ dan pupuk Organonitrofos masing-masing dengan dosis $400 \mathrm{~kg}$ $\mathrm{ha}^{-1}, 300 \mathrm{~kg} \mathrm{ha}^{-1}, 400 \mathrm{~kg} \mathrm{ha}^{-1}$ dan $20 \mathrm{t} \mathrm{ha}^{-1}$ serta bahanbahan kimia untuk analisis tanah dan tanaman. Petak percobaan berukuran $3 \mathrm{~m} \times 4 \mathrm{~m}$ dengan jarak tanam 70 $\mathrm{cm} \times 20 \mathrm{~cm}$. Perlakuan percobaan terdiri dari 4 perlakuan yaitu : $\mathrm{A}=$ olah tanah minimum; $\mathrm{B}=$ olah tanah minimum + herbisida; $\mathrm{C}=$ olah tanah sempurna; olah tanah sempurna + herbisida; dan D = olah tanah sempurna + herbisida. Perlakuan diulang sebanyak 4 kali. Percobaan disusun dalam Rancangan Acak Kelompok (RAK).

Aplikasi herbisida pada tahap I dilakukan pada petak percobaan yang mendapatkan perlakuan herbisida dengan dosis 3,33 1 ha $^{-1}$ pada satu minggu sebelum pengolahan tanah dan penyemprotan pada tahap ke II dilakukan 3 minggu setelah tanam. Pemberian pupukOrganonitrofos dilakukan pada saat awal penanaman. Pemberian pupuk anorganik dilakukan pada saat 2 minggu setelah tanam (MST), kecuali urea yang diberikan dua kali yaitu $1 / 2$ dosis pada saat 2 MST dan $1 / 2$ dosis pada 7 MST. Jagung dipanen pada saat saat berumur 105-115 hari setelah tanam dengan ciri-ciri yaitu klobot sudah berwarna coklat, rambut berwarna hitam dan kering, biji jagung bila ditekan dengan kuku tidak membekas.Variabel yang diamati pada penelitian ini adalah tinggi tanaman, jumlah daun, analisis tanah, analisis tanaman, produksi jagung, serapan hara tanaman, uji korelasi dan uji ekonomis.

\section{HASIL DAN PEMBAHASAN}

Sifat Kimia Tanah Awal dan Akhir. Hasil analisis tanah Ultisol pada lokasi penelitian ini (Tabel 1) menunjukkan bahwa reaksi tanah awal memiliki kategori

Tabel 1. Sifat kimia tanah awal pada musim ketiga tanaman jagung dan hasil analisis sifat kimia tanah akhir tanaman jagung.

\begin{tabular}{|c|c|c|c|c|c|}
\hline \multirow[b]{2}{*}{ Jenis Analisis } & & \multicolumn{4}{|c|}{ Perlakuan } \\
\hline & & A & B & $\mathrm{C}$ & $\mathrm{D}$ \\
\hline \multirow{4}{*}{$\mathrm{pH}\left(\mathrm{H}_{2} \mathrm{O}\right)$} & Awal & 6,02 & 6,03 & 6,03 & 6,40 \\
\hline & & $(\mathrm{AM})$ & $(\mathrm{AM})$ & $(\mathrm{AM})$ & $(\mathrm{AM})$ \\
\hline & Akhir & 6,23 & 6,18 & 6,47 & 6,20 \\
\hline & & $(\mathrm{AM})$ & $(\mathrm{AM})$ & $(\mathrm{AM})$ & (AM) \\
\hline \multirow{4}{*}{$\begin{array}{c}\text { N- Total } \\
(\%)\end{array}$} & Awal & 0,15 & 0,13 & 0,17 & 0,17 \\
\hline & & (R) & (R) & (R) & (R) \\
\hline & Akhir & 0,18 & 0,13 & 0,18 & 0,14 \\
\hline & & (R) & (R) & (R) & (R) \\
\hline \multirow{4}{*}{$\begin{array}{l}\text { P- Tersedia } \\
\quad(\mathrm{ppm})\end{array}$} & Awal & 6,41 & 4,84 & 5,82 & 6,62 \\
\hline & & (R) & (R) & (R) & (R) \\
\hline & Akhir & 19,54 & 17,28 & 16,88 & 15,34 \\
\hline & & $(\mathrm{ST})$ & (ST) & (ST) & (ST) \\
\hline \multirow{4}{*}{$\begin{array}{c}\mathrm{K}-\mathrm{dd} \\
\left(\mathrm{cmol} \mathrm{kg}^{-1}\right)\end{array}$} & Awal & 0,38 & 0,47 & 0,37 & 0,40 \\
\hline & & (R) & (R) & (R) & (R) \\
\hline & Akhir & 0,41 & 0,42 & 0,41 & 0,41 \\
\hline & & (R) & (R) & (R) & (R) \\
\hline \multirow{4}{*}{$\begin{array}{c}\text { C- Total } \\
(\%)\end{array}$} & Awal & 1,13 & 0,94 & 1,26 & 1,14 \\
\hline & & (R) & (SR) & (R) & (R) \\
\hline & Akhir & 1,33 & 1,38 & 1,50 & 1,43 \\
\hline & & (R) & (R) & (R) & (R) \\
\hline
\end{tabular}

Keterangan: A (olah tanah minimum), B (olah tanah minimum + herbisida), C (olah tanah sempurna), D (olah tanah sempurna + herbisida), R (Rendah), S (Sedang), ST (Sangat tinggi), SR (Sangat rendah), N (netral), AM (Agak masam) (Balai Penelitian Tanah, 2005) 
agak masam (pH 6,02-6,40). Hasil analisis tanah akhir menunjukkan terjadi peningkatan $\mathrm{pH}$ tanah walaupun masih tergolong kategori yang sama yaitu agak masam. Hal ini dapat disebabkan oleh peningkatan dosis pupuk Organonitrofos menjadi $20 \mathrm{t} \mathrm{ha}^{-1}$. Sesuai dengan pendapat Nurmasyitah (2013) yang menyatakan bahwa aktifitas dan metabolisme biologi mampu menghasilkan dan melepaskan senyawa-senyawa organik yang berperan dalam mengikat kation-kation logam penyebab kemasaman tanah sehingga meningkatkan $\mathrm{pH}$.

Kandungan N-total, K-dd dan C-Total hasil analisis tanah awal dan akhir tergolong kategori rendah (Tabel 1). Rendahnya kandungan nitrogen disebabkan unsur nitrogen merupakan salah satu unsur pupuk yang diperlukan dalam jumlah paling banyak, namun keberadaannya dalam tanah sangat mobil sehingga mudah hilang dari tanah melalui pencucian (Nainggolan, dkk., 2009). Sementara tinggi rendahnya kandungan karbon dalam tanah dipengaruhi oleh penambahan bahan organik ke dalam tanah, aktivitas mikroorganisme dalam merombak bahan organik tanah, evapotranspirasi atau terikut ketika panen (Nariratih, dkk., 2013).

Ketersedian P di kebanyakan tanah maksimum pada rentang pH 6,0 - 6,5 (Munawar, 2011). Kandungan $\mathrm{P}$ - tersedia yang sangat tinggi pada analisis tanah akhir dapat disebabkan olah penambahan pupuk Organonitrofos. Munawar (2011) menyatakan bahwa penjerapan $\mathrm{P}$ oleh oksida Fe dan $\mathrm{Al}$ berkurang seiring dengan meningkatnya $\mathrm{pH}$ tanah. Jika $\mathrm{pH}$ ditingkatkan, aktivitas Fe dan $\mathrm{Al}$ turun, sehingga adsorpsi/ presipitasi berkurang dan meningkatkan konsentrasi P larut. Menurut Adnan dan Manfaraziah (2012), gulma yang mati akan mengalami pelapukan sehingga gulma tersebut menjadi tambahan unsur hara yang tersedia dan dapat diserap oleh tanaman.

Pertumbuhan Vegetatif. Pada fase vegetatif tinggi tanaman akan terus meningkat pada umur tertentu dan kemudian pertumbuhannya akan terhenti (Gambar 1). Hasil penelitian menunjukkan bahwa perlakuan olah tanah berpengaruh terhadap tinggi tanaman pada umur 7 minggu setelah tanam (MST) (Tabel 2). Hal ini dapat disebabkan oleh penggunaan mulsa pada perlakuan olah tanah minimum. Penggunaan mulsa dapat memperbaiki sifat fisik tanah, mengurangi evaporasi tanah dan sebagai penambah unsur hara yang dibutuhkan pada mulsa yang dapat meningkatkan pertumbuhan tanaman. Menurut Surtinah (2013), serasah jagung manis sebagai mulsa mengandung beberapa unsur hara makro dan mikro yang sangat dibutuhkan untuk pertumbuhan tanaman. Hasil penelitian menunjukkan bahwa perlakuan olah tanah tidak berpengaruh terhadap jumlah daun 7 MST (Tabel 2). Menurut Subekti, dkk. (2012), jagung merupakan tanaman hari pendek, jumlah daunnya dikendalikan oleh genotipe, lama penyinaran, dan suhu serta ditentukan pada saat inisiasi bunga jantan.

Produksi Tanaman Jagung. Hasil penelitian menunjukan bahwa perlakuan pengolahan tanah tidak berpengaruh terhadap bobot biji, bobot brangkasan (Tabel 4) dan bobot kering tanaman (Tabel 5). Data hasil penelitian menunjukkan (Tabel 3) bahwa bobot biji kering panen; bobot biji kering oven dan bobot biji kadar air $14 \%$ pada perlakuan olah tanah minimum dengan rerata masing-masing sebesar $11,07 \mathrm{t} \mathrm{ha}^{-1} ; 7,07 \mathrm{t} \mathrm{ha}^{-1}$ dan 7,86 $\mathrm{t} \mathrm{ha}^{-1}$. Sedangkan produksi bobot biji kering panen; bobot biji kering oven dan bobot biji kadar air $14 \%$ pada perlakuan olah tanah sempurna dengan rerata masing-masing sebesar $10,00 \mathrm{tha}^{-1} ; 6,48 \mathrm{t} \mathrm{ha}^{-1}$; dan 7,25 t ha ${ }^{-1}$. Hasil penelitian Musa, dkk. (2007) menunjukan bahwa perlakuan olah tanah sempurna memiliki produksi tanaman yang lebih tinggi dibandingkan dengan perlakuan olah tanah minimum, yaitu dengan produksi berturut-turut $8,40 \mathrm{t} \mathrm{ha}^{1}$ dan $6,35 \mathrm{t} \mathrm{ha}^{-1}$. Sementara hasil penelitian yang dilakukan Oktaviansyah (2015) menunjukkan bahwa perlakuan olah tanah minimum

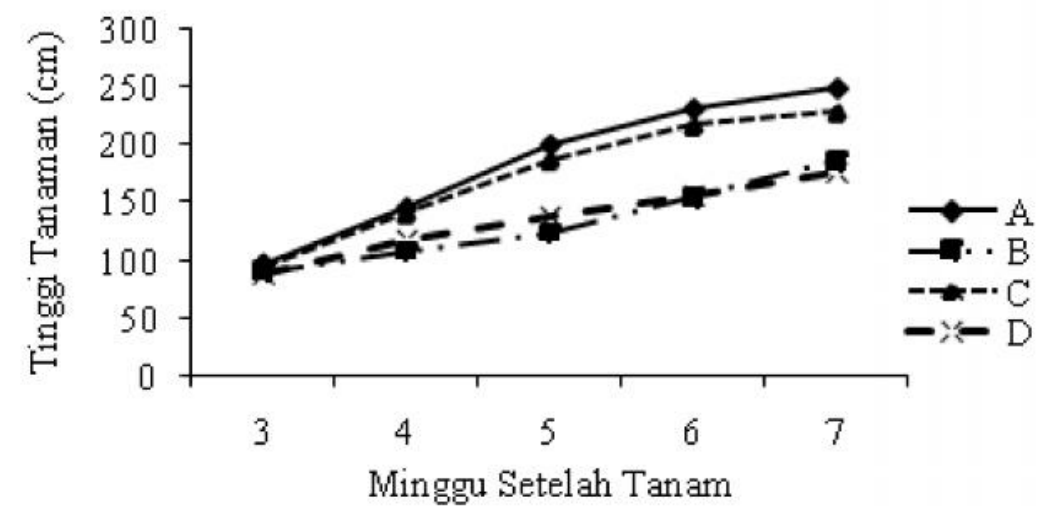

Gambar 1. Pengaruh pengolahan tanah terhadap tinggi tanaman jagung. 
Tabel 2. Pengaruh pengolahan tanah terhadap tinggi dan jumlah daun tanaman jagung 7 MST.

\begin{tabular}{lcc}
\hline \multicolumn{1}{c}{ Perlakuan } & Tinggi Tanaman $(\mathrm{cm})$ & Jumlah daun (helai) \\
\hline Olah tanah minimum & $248,9 \mathrm{c}$ & 13,03 \\
Olah tanah minimum + herbisida & $183,7 \mathrm{a}$ & 13,05 \\
Olah tanah sempurna & $229,2 \mathrm{~b}$ & 12,65 \\
Olah tanah sempurna + herbisida & $176,1 \mathrm{a}$ & 12,55 \\
\hline \multicolumn{1}{c}{ BNT 5\% } & 14,44 & tn \\
\hline
\end{tabular}

Keterangan: Kolom yang diikuti dengan huruf yang sama tidak berbeda nyata pada uji BNT taraf 5\%

Tabel 3. Pengaruh pengolahan tanah terhadap produksi biji jagung ton ha-1.

\begin{tabular}{lccc}
\hline \multirow{2}{*}{ Perlakuan } & \multicolumn{2}{c}{ Bobot pipilan jagung $\left(\mathrm{t} \mathrm{ha}^{-1}\right)$} \\
\cline { 2 - 2 } & Biji kering panen & Biji kering oven & Biji kadar air 14\% \\
\hline Olah tanah minimum & 11,07 & 7,07 & 7,86 \\
Olah tanah minimum + herbisida & 8,75 & 5,52 & 6,15 \\
Olah tanah sempurna & 10,00 & 6,48 & 7,25 \\
Olah tanah sempurna + herbisida & 10,00 & 6,74 & 7,48 \\
\hline
\end{tabular}

Tabel 4. Pengaruh pengolahan tanah terhadap bobot brangkasan tanaman jagung.

\begin{tabular}{lcc}
\hline \multirow{2}{*}{ Perlakuan } & \multicolumn{2}{c}{ Bobot Berangkasan $\left(\mathrm{t} \mathrm{ha}^{-1}\right)$} \\
\cline { 2 - 3 } & Kering panen & Kering oven \\
\hline Olah tanah minimum & $21,44 \mathrm{~b}$ & 7,86 \\
Olah tanah minimum + herbisida & $18,21 \mathrm{ab}$ & 6,15 \\
Olah tanah sempurna & $18,21 \mathrm{ab}$ & 7,25 \\
Olah tanah sempurna + herbisida & $16,18 \mathrm{a}$ & 7,48 \\
\hline \multicolumn{1}{c}{ BNT 5\% } & 2,61 & tn \\
\hline
\end{tabular}

Keterangan: Kolom yang diikuti dengan huruf yang sama tidak berbeda nyata pada uji BNT taraf 5\%

Tabel 5. Pengaruh pengolahan tanah terhadap bobot kering tanaman jagung.

\begin{tabular}{lccccc}
\hline \multicolumn{1}{c}{ Perlakuan } & \multicolumn{3}{c}{ Bobot kering tanaman jagung $\left(\mathrm{t} \mathrm{ha}^{-1}\right)$} & \\
\cline { 2 - 3 } & Brangkasan oven & Bonggol oven & Biji kering oven & Total \\
\hline Olah tanah minimum & 6,98 & 1,50 & 7,07 & 15,56 \\
Olah tanah minimum + herbisida & 6,54 & 1,13 & 5,52 & 13,19 \\
Olah tanah sempurna & 6,22 & 1,31 & 6,48 & 14,01 \\
Olah tanah sempurna + herbisida & 5,86 & 1,28 & 6,74 & 13,88 \\
\hline
\end{tabular}

memiliki produksi tanaman yang lebih tinggi dibandingkan dengan olah tanah sempurna dengan produksi sebesar berturut-turut 7,54 $\mathrm{t} \mathrm{ha}^{-1}$ dan $6,37 \mathrm{t} \mathrm{ha}^{-1}$. Ditinjau dari hasil produksi, bahwa perlakuan olah tanah tidak berpengaruh namun dari segi biaya dan rasio $\mathrm{B} / \mathrm{C}$ menunjukan bahwa perlakuan olah tanah minimum lebih ekonomis dibandingkan perlakuan olah tanah lainnya.
Serapan Hara Tanaman. Hasil penelitian menunjukkan bahwa sistem olah tanah tidak berpengaruh terhadap serapan hara $\mathrm{N}$ pada brangkasan, biji, bonggol dan total serapan $\mathrm{N}$ tanaman jagung. Total serapan $\mathrm{N}$ pada perlakuan olah tanah minimum, olah tanah sempurna + herbisida, olah tanah minimum + herbisida dan olah tanah sempurna masing-masing 
sebesar $172,38 \mathrm{~kg} \mathrm{ha}^{-1} ; 162,08 \mathrm{~kg} \mathrm{ha}^{-1}, 158,45 \mathrm{~kg} \mathrm{ha}^{-1}$ dan $151,50 \mathrm{~kg} \mathrm{ha}^{-1}$ (Tabel 6). Serapan N yang terangkut pada perlakuan olah tanah minimum sejalan dengan berat kering brangkasan, biji dan total bahan kering yang dihasilkan. Menurut Lakitan (2012), pertumbuhan tanaman ditunjukkan oleh bertambahnya ukuran dan berat kering tanaman yang dicerminkan dengan bertambahnya protoplasma yang terjadi karena bertambahnya ukuran sel. Ketersediaan unsur hara N yang rendah (Tabel 1) menyebabkan pasokan $\mathrm{N}$ dari akar tidak cukup, sehingga $\mathrm{N}$ di dalam daun-daun yang telah menua akan dimobilisasi untuk memasok organ tanaman yang masih muda (Munawar, 2011).

Hasil penelitian menunjukkan bahwa total serapan $P$ menunjukkan hasil yang tidak berbeda antar perlakuan (Tabel 7). Uji korelasi antara serapan P terangkut terhadap bobot brangkasan total menunjukkan korelasi yang positif artinya serapan $\mathrm{P}$ tanaman mempengaruhi tingginya biomassa tanaman. Unsur hara P mempunyai fungsi dan peran yang sangat vital dalam proses pertumbuhan dan perkembangan tanaman. Pasokan unsur hara $\mathrm{P}$ dalam jumlah cukup dapat meningkatkan kualitas buah, pakan ternak, sayuran dan biji tanaman (Munawar, 2011). Hasil penelitian menunjukkan bahwa perlakuan sistem olah tanah tidak berpengaruh terhadap serapan K brangkasan, bonggol, biji dan total tanaman jagung (Tabel 8). Pasokan K yang cukup akan menjamin fungsi daun selama pertumbuhan buah dan jumlah gula buah dan berperan dalam sintesis protein dan memacu konversi nitrat menjadi protein sehingga meningkatkan efisiensi $\mathrm{N}$ dalam tanah. Kandungan $\mathrm{K}$ di dalam jaringan yang cukup akan dapat mempertahankan kandungan air dalam jaringan pada kondisi tercekam sehingga tahan akan kekeringan dan serangan hama dan penyakit (Munawar, 2011).

Uji Ekonomis. Perhitungan yang dilakukan terhadap hasil yaitu dengan membandingkan hasil panen secara ekonomi dengan pengeluaran akibat tenaga kerja. Apabila nilai rasio $>1$ maka input yang diuji tersebut memiliki nilai ekonomis yang menguntungkan dan

Tabel 6. Pengaruh pengolahan tanah terhadap $\mathrm{N}$ yang terangkut panen.

\begin{tabular}{lcccc}
\hline \multirow{2}{*}{ Perlakuan } & \multicolumn{3}{c}{ Serapan hara N tanaman jagung $\left(\mathrm{kg} \mathrm{ha}^{-1}\right)$} \\
\cline { 2 - 5 } & Brangkasan & Bonggol & Biji & Total \\
\hline Olah tanah minimum & 50,52 & 6,31 & 115,55 & 172,38 \\
Olah tanah minimum + herbisida & 54,97 & 5,79 & 97,69 & 158,45 \\
Olah tanah sempurna & 50,83 & 5,35 & 95,32 & 151,50 \\
Olah tanah sempurna + herbisida & 46,53 & 5,10 & 110,46 & 162,08 \\
\hline
\end{tabular}

Tabel 7. Pengaruh pengolahan tanah terhadap $\mathrm{P}$ yang terangkut panen.

\begin{tabular}{lcccc}
\hline \multirow{2}{*}{ Perlakuan } & \multicolumn{3}{c}{ Serapan hara P tanaman jagung $\left(\mathrm{kg} \mathrm{ha}^{-1}\right)$} \\
\cline { 3 - 5 } & Brangkasan & Bonggol & Biji & Total \\
\hline Olah tanah minimum & 21,36 & 3,45 & 32,54 & 57,36 \\
Olah tanah minimum + herbisida & 23,82 & 2,70 & 24,84 & 51,35 \\
Olah tanah sempurna & 18,97 & 2,87 & 27,78 & 49,62 \\
Olah tanah sempurna + herbisida & 20,57 & 3,28 & 26,94 & 50,80 \\
\hline
\end{tabular}

Tabel 8. Pengaruh pengolahan tanah terhadap K yang terangkut panen.

\begin{tabular}{lcccc}
\hline \multirow{2}{*}{ Perlakuan } & \multicolumn{4}{c}{ Serapan hara K tanaman jagung $\left(\mathrm{kg} \mathrm{ha}^{-1}\right)$} \\
\cline { 2 - 4 } & Brangkasan & Bonggol & Biji & Total \\
\hline Olah tanah minimum & 72,64 & 4,21 & 73,75 & 150,60 \\
Olah tanah minimum + herbisida & 64,78 & 3,95 & 57,05 & 125,78 \\
Olah tanah sempurna & 65,98 & 4,24 & 65,30 & 135,52 \\
Olah tanah sempurna + herbisida & 56,89 & 4,40 & 65,44 & 126,72 \\
\hline
\end{tabular}


sebaliknya apabila nilai rasio $<1$ maka input yang diuji tersebut memiliki nilai ekonomis yang merugikan. Hasil analisis menunjukkan bahwa perlakuan olah tanah minimum memiliki nilai $\mathrm{B} / \mathrm{C}$ rasio tertinggi yaitu sebesar 2,11 . Selanjutnya nilai rasio tertinggi kedua, ketiga dan keempat terdapat pada perlakuan olah tanah minimum + herbisida, olah tanah sempurna + herbisida dan olah tanah sempurna dengan nilai rasio secara berturut-turut sebesar 1,$84 ; 1,77$; dan 1,57 . Perlakuan yang memiliki nilai rasio terendah yaitu terdapat pada perlakuan olah tanah sempurna yaitu 1,57 (Tabel 9). Teknologi pengolahan tanah minimum lebih baik dalam budidaya tanaman jagung sehingga dapat menjadi rekomendasi untuk petani.

Uji Korelasi. Produksi bobot biji, bonggol, brangkasan dan jumlah daun berkorelasi nyata terhadap serapan hara N, P dan K. Hal ini akibat adanya akumulasi unsur hara melalui proses penyerapan dan pengubahan hasil fotosintesis ke dalam bentuk organ tanaman sehingga meningkatkan bobot kering pipilan dan brangkasan. Hal tersebut tercermin dengan nilai koefisien korelasi (r) yang mendekati nilai 1. Selanjutnya serapan hara $\mathrm{K}$ berkorelasi nyata terhadap tinggi tanaman jagung (Tabel 10).

Tabel 9. Indeks uji ekonomis pengaruh olah tanah terhadap hasil produksi tanaman jagung.

\begin{tabular}{lc}
\hline \multicolumn{1}{c}{ Perlakuan } & Rasio \\
\hline Olah tanah minimum & 2,11 \\
Olah tanah minimum + herbisida & 1,84 \\
Olah tanah sempurna & 1,57 \\
Olah tanah sempurna + herbisisa & 1,77 \\
\hline
\end{tabular}

Keterangan: Bila rasio >1 maka pengolahan tanah yang diuji memiliki nilai ekonomis yang baik

Tabel 10. Uji korelasi antara serapan NPK dengan pertumbuhan dan produksi tanaman jagung.

\begin{tabular}{cllc}
\hline No & \multicolumn{1}{c}{ Uji korelasi } & \multicolumn{1}{c}{ Persamaan } & $\mathrm{R}$ \\
\hline 1 & N vs Tinggi tanaman & $\mathrm{y}=159,72+0,9914 \mathrm{x}$ & $0,24 \mathrm{tn}$ \\
2 & P vs Tinggi tanaman & $\mathrm{y}=204,91+0,2402 \mathrm{x}$ & $0,03 \mathrm{tn}$ \\
3 & K vs Tinggi tanaman & $\mathrm{y}=96,728+1,7406 \mathrm{x}$ & $0,59^{*}$ \\
4 & N vs Jumlah Daun & $\mathrm{y}=10,541+0,0449 \mathrm{x}$ & $0,55^{*}$ \\
5 & P vs Jumlah Daun & $\mathrm{y}=10,698+0,1001 \mathrm{x}$ & $0,54^{*}$ \\
6 & K vs Jumlah Daun & $\mathrm{y}=10,79+0,0312 \mathrm{x}$ & $0,54^{*}$ \\
7 & N vs Bobot Biji & $\mathrm{y}=188,91+59,801 \mathrm{x}$ & $0,94^{*}$ \\
8 & P vs Bobot Biji & $\mathrm{y}=378,12+216,77 \mathrm{x}$ & $0,95^{*}$ \\
9 & K vs Bobot Biji & $\mathrm{y}=27,299+98,275 \mathrm{x}$ & $0,99^{*}$ \\
10 & N vs Bobot Bonggol & $\mathrm{y}=97,547+214,22 \mathrm{x}$ & $0,84^{*}$ \\
11 & P vs Bobot Bonggol & $\mathrm{y}=75,069+399,65 \mathrm{x}$ & $0,95^{*}$ \\
12 & K vs Bobot Bonggol & $\mathrm{y}=20,202+306,18 \mathrm{x}$ & $0,86^{*}$ \\
13 & N vs Bobot Brangkasan & $\mathrm{y}=318,07+120,02 \mathrm{x}$ & $0,93^{*}$ \\
14 & P vs Bobot Brangkasan & $\mathrm{y}=974,11+256,4 \mathrm{x}$ & $0,87^{*}$ \\
15 & K vs Bobot Brangkasan & $\mathrm{y}=536,76+90,171 \mathrm{x}$ & $0,98^{*}$ \\
\hline
\end{tabular}

Keterangan: $\mathrm{r}=$ koefisien korelasi linier, ${ }^{*}=$ berbeda nyata pada taraf $5 \%, \mathrm{tn}=$ tidak berbeda nyata pada taraf $5 \%$ 


\section{KESIMPULAN}

Perlakuan sistem olah tanah minimum berpengaruh nyata meningkatkan tinggi tanaman, bobot brangkasan panen dan C terangkut pada bonggol jagung, namun tidak berpengaruh terhadap kandungan $\mathrm{C}$ organik, N, dan K pada pertanaman jagung. Olah tanah minimum lebih menguntungkan dari pada perlakuan olah tanah minimum + herbisida, olah tanah sempurna, dan olah tanah sempurna+ herbisida pada pertanaman jagung pada musim tanam ketiga di tanah Ultisol Gedung Meneng Bandar Lampung.

\section{SANWACANA}

Penulis menyampaikan terima kasih atas dukungan dana dan fasilitas dari kerjasama antara Fakultas Pertanian Universitas Lampung dan Yokohama University.

\section{DAFTAR PUSTAKA}

Adnan, H. dan Manfaraziah. 2012. Aplikasi beberapa dosis herbisida glifosat dan paraquat pada sistem tanpa olah tanah (TOT) serta pengaruhnya terhadap sifat kimia tanah, karakteristik gulma dan hasil kedelai. Jurnal Agrista. 16 (3): 135-145.

Balai Penelitian Tanah. 2005. Petunjuk Teknis Analisis Kimia Tanah, Tanaman, Air dan Pupuk. Balai Penelitian Tanah. Bogor. $136 \mathrm{hlm}$.

BPS. 2015. Data Produktivitas Jagung Indonesia pada tahun 2014. Available online at http:// www.bps.go.id, [4 Oktober 2015].

Departemen Pertanian. 2006. Pedoman Umum Budidaya Pertanian Pada Lahan Pegunungan. Peraturan Menteri Pertanian Nomor 47/ Permentan/OT.140/10/2006. Departemen Pertanian. Jakarta. 45 hlm.

Direktorat Jenderal Tanaman Pangan. 2015. Buku Pedoman GP-Ptt Jagung. Jakarta. 89 hlm.

Eriawan, B. dan Nadimin. 2011. Peranan Bahan Organik terhadap Kesuburan Tanah dan Upaya Pengeolaannya. Balai Pengkajian Teknologi Pertanian. Jawa Barat. 6 hlm.

Indrasari, A. dan A. Syukur. 2006. Pengaruh pemberian pupuk kandang dan unsur hara mikro terhadap pertumbuhan jagung pada Ultisol yang dikapur. Jurnal Ilmu Tanah dan Lingkungan. 6(2): 116123.
Lakitan, B. 2012. Dasar-Dasar Fisiologi Tumbuhan. PT Raja Grafindo Persada. Jakarta. 205 hlm.

Munawar, A. 2011. Kesuburan Tanah dan Nutrisi Tanaman. IPB-Press. Bogor. $240 \mathrm{hlm}$.

Musa, Y., Nasaruddin, dan M. A. Kuruseng. 2007. Evaluasi produktivitas jagung melalui pengelolaan populasi tanaman, pengolahan tanah dan dosis pemupukan. Jurnal agrosistem. 3(1): 21-33.

Mustafa, M., A. Ahmad, M. Ansar, dan M. Syafiuddin. 2012. Dasar-Dasar Ilmu Tanah. Fakultas Pertanian Universitas Hasanuddin. Makasar. 169 hlm.

Nainggolan, G.D., Suwardi, dan Darmawan. 2009. Pola pelepasan nitrogen dari pupuk tersedia lambat (slow release fertilizer) urea-zeolit-asam humat. Jurnal Zeolit Indonesia. 8(2): 89-96.

Nariratih, I., M.M.B. Damanik dan G. Sitanggang. 2013. Ketersediaan nitrogen pada tiga jenis tanah akibat pemberian tiga bahan organik dan serapannya pada tanaman jagung. Jurnal Online Agroekoteknologi. 1(3): 479-488.

Nurmasyitah, Syafruddin, dan M. Sayuthi. 2013. Pengaruh jenis tanah dan dosis fungi mikoriza arbuskular pada tanaman kedelai terhadap sifat kimia tanah. Jurnal Agrista. 17(3): 103-110.

Oktaviansyah, H. 2015. Pengaruh Sistem Olah Tanah terhadap Pertumbuhan, Serapan Hara dan Produksi Tanaman Jagung (Zea Mays L.) pada Tanah Ultisol Gedung Meneng Bandar Lampung. Skripsi. Universitas Lampung. $75 \mathrm{hlm}$.

Rachman, A., A. Dariah, dan E. Husen. 2004. Konservasi Tanah Pada Lahan Kering Berlereng. Pusat Penelitian dan Pengembangan Tanah Agroklimat. Badan Litbang Pertanian. Departemen Pertanian. 204 hlm.

Subekti, N.A., Syafruddin, R. Efendi, dan S. Sunarti. 2012. Jagung: Teknik Produksi dan Pengembangan. Balai penelitian Tanaman Serealia. Maros. $426 \mathrm{hlm}$.

Surtinah. 2013. Pengujian kandungan unsur hara dalam kompos yang berasal dari serasah tanaman jagung manis (Zea mays L.). Jurnal Ilmiah Pertanian 11(1):16-25.

Utomo, M. 2006. Olah Tanah Konservasi. Hand out Pengelolaan Lahan Kering Berkelanjutan. Universitas Lampung. Bandar Lampung. $25 \mathrm{hlm}$. 